\title{
ARTERIAL BLOOD OXYGEN SATURATION AND ITS DYNAMICS DUE TO THE ENVIRONMENTAL ELECTROMAGNETIC CONDITIONS
}

\author{
S.O. Mamilov ${ }^{1 *}$, Yu.P. Gorgo ${ }^{1,2}$, S.S. Yesmann ${ }^{1}$, M. Vácziová ${ }^{3}$, A. Prigancová ${ }^{3}$, B. Pet'ko ${ }^{4}$ \\ ${ }^{1}$ Institute of Applied Problems of Physics and Biophysics, NAS of Ukraine, Kyiv, Ukraine \\ ${ }^{2}$ Igor Sikorsky Kyiv Polytechnic Institute, Kyiv, Ukraine \\ ${ }^{3}$ Earth Science Institute of the Slovak Academy of Sciences, Bratislava, Slovak Republic \\ ${ }^{4}$ Institute of Parasitology of the Slovak Academy of Sciences, Kosice, Slovak Republic \\ *Corresponding author: MamilovSO@nas.gov.ua \\ Received 25 March 2019; Accepted 19 Aplril 2019
}

Background. As widely known, the geomagnetic field intensity does change abruptly during global magnetic disturbances specified as magnetic storms. Those are due to the changing solar activity influencing solar wind parameters and the state of the magnetosphere. This chain of physical processes with their origin in the Sun is described as the space weather. To understand the space weather effects in the environment is most important since those are related to the biosphere as well. Namely, the low-frequency geomagnetic field dynamics, linked with space weather conditions, seems to be a quite probable factor influencing both the pathological and functional state of a human being and biological objects, in general, during magnetic storms.

Objective. In this study, the dynamics of an oxygen saturation parameter in human arterial blood is analyzed with regard to extreme space weather when magnetic storms occur.

Methods. Experimental setup for measuring changes of the relative concentration of oxyhemoglobin in arterial blood (saturation of arterial blood with oxygen), is a pulse oximeter-spectrophotometer. Measurements were carried out using pulse-oximetry sensor covering the first phalanx of a finger, and laser radiation was directed to the side of the second phalanx. The He-Ne laser with a wavelength of $632 \mathrm{~nm}$ was used as a source of electromagnetic radiation. Observational values of the geomagnetic field with a high-time resolution $(1-\mathrm{sec})$ are obtained from the midlatitude Hurbanovo Geomagnetic Observatory (Slovak Republic). Deviations/oscillation ranges regarding the average value were calculated at all frequencies, and low pass filter was applied from the "Seewave-1.7.6" package (F-filter) for frequencies of $0.1,0.5,0.01,0.05,0.001$, and $0.0001 \mathrm{~Hz}$. The data on magnetic storms for 2015 were derived from the file of Kyoto Geomagnetic Center which indicated the dates and the amplitudes of magnetic storms on the Earth.

Results. The following variables were analyzed: the average arterial oxygen saturation at the patient's rest, peak-to-peak value of saturation, changes in the average oxygen saturation under laser radiation. A group of 33 persons was daily monitored from March 30, 2015, to May 25, 2015. In the presence of Earth's magnetic field disturbances, the average value of arterial oxygen saturation at the state of rest in 29 persons out of 33 was $93.9 \pm 0.9 \%$, peak-to-peak value of oxygen was $1.25 \pm 0.24 \%$, and the change in the average arterial oxygen saturation under laser radiation made up $2.34 \pm 0.41 \%$. In 4 persons under study the peak-to-peak value of saturation at rest did not differ from the case of the undisturbed geomagnetic field.

Conclusions. The results of this study of some blood parameters, namely the oxygen saturation (and oxygenetion) value of the arterial blood and its dynamics due to exposed laser radiation in case of both the undisturbed and disturbed GMF, can be summarized as follows: the decrease of the blood oxygenation in case of the disturbed GMF (magnetic storm conditions) is quite apparent although more detailed statistical investigations along with biophysical explanations are needed; the presence of some experimentees in the observed group who have constant sweep of arterial blood oxygen saturation is, in our opinion, an aspect to explain the different frequency of tick attacks on various people although strict medical and epidemiological investigations are needed; the dynamics of the decrease of oxygen saturation in the arterial blood of human beings exposed to laser radiation, in persons with sensitivity to radiation, may be an indicator of the degree of influence of perturbations of the geomagnetic field.

Keywords: oxygen saturation of arterial blood; geomagnetic field; laser; irradiation.

\section{Introduction}

As widely known, the geomagnetic field (GMF) intensity does change abruptly during global magnetic disturbances specified as magnetic storms. Those are due to the changing solar activity influ- encing solar wind parameters and the state of the magnetosphere. This chain of physical processes with their origin in the Sun is described as the space weather [1]. To understand the space weather effects in the environment is most important since those are related to the biosphere as well [2]. 
Namely, the low-frequency GMF dynamics, linked with space weather conditions, seems to be a quite probable factor influencing both the pathological and functional state of a human being and biological objects, in general, during magnetic storms [3].

In particular, blood functional parameters are shown to be sensitive to space weather. This fact appears to be directly related to specific biological tasks as e.g. why tick attacks are so optional [3]. In this study, the dynamics of the most important blood functional parameter - an oxygen saturation parameter in human arterial blood - is analyzed with regard to extreme space weather when magnetic storms occur [4].

\section{Materials and Methods}

Experimental setup for measuring changes of the relative concentration of oxyhemoglobin in arterial blood (saturation of arterial blood with oxygen), that being decisive for normal human life activities, is a pulse oximeter-spectrophotometer developed in the Institute of Applied Problems of Physics and Biophysics of NAS of Ukraine [5]. A sensor operating in transmitted and back-scattered light based on a standard pair of pulse-oximetry Light emitted diodes (LEDs) V97B $\left(\lambda_{\max }=660 \mathrm{~nm}\right.$ and $\left.940 \mathrm{~nm}\right)$ and a silicon photodiode BPW34 was used in experiments. LEDs emission spectra and photodiode spectral sensitivity are shown in Fig. 1.

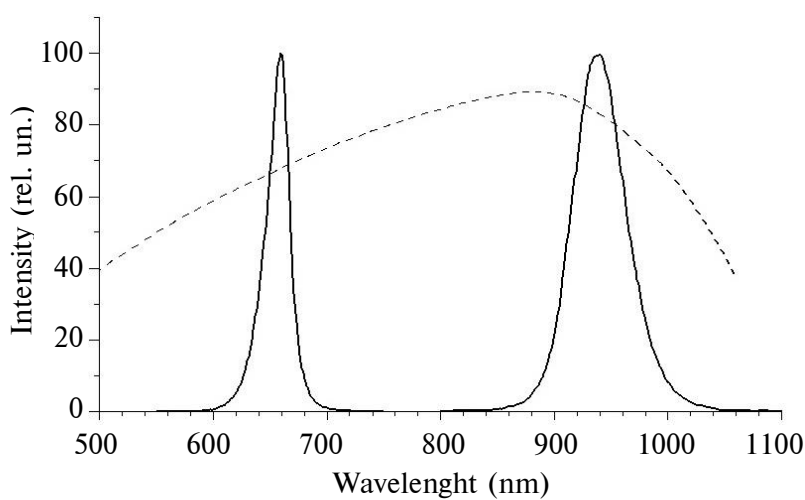

Figure 1: Light emitted diodes emission spectra; $\lambda_{1}=660 \mathrm{~nm}$, $\lambda_{2}=940 \mathrm{~nm}$. The dotted line shows the spectral sensitivity of the photodiode BPW34

To reduce the impact of patient involuntary movements on photoplethysmogram signals the sensor was built as a clothespin with adjustable pressing force on a finger (Fig. 2) which allowed us to reduce significantly the signal instability.

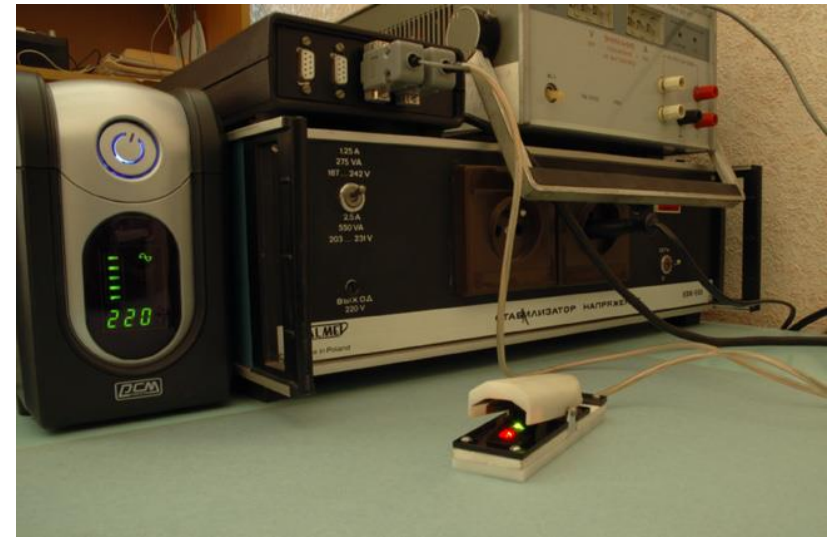

Figure 2: Sensor for measuring the relative concentration of oxyhemoglobin in blood

Control of sensor operation, data acquisition, and transfer are provided with a multi-channel measuring unit connected to PC. That performs information processing, displays output data and saves signal records on HDD. The measuring unit includes input and output paths and microcontroller managing both paths and providing two-way information exchange with PC.

The microcontroller sets the sequence of the LEDs power supply and photodiodes inquiry, provides the continuity of data measurement saving them to the internal memory block during those periods when $\mathrm{PC}$ computer interrupts the exchange. The microcontroller is a microprocessor unit which consists of a microprocessor, RAM, ROM, decoder, timer, quartz clock generator, and input-output ports.

The input path of the measuring unit consists of amplifiers with circuits of matching with a signal source, inputs switch, sampling and storage device, and 16-bit ADC. The input path operates with time division of channels. The sampling frequency is $f_{s}=348 \mathrm{~Hz}$.

The output path includes 10-bit DAC, pulse formers, and output signal switches. The mode of operation of the measuring unit is a set with the special software. The software interface provides a setting of necessary operating parameters from PC:

- selecting the number of LEDs and photodiodes;

- switching sequence of output signals (LEDs supply);

- selecting mode of the setting of a gain factor of input signals and amplitude of output pulses (automatic and manual modes).

Signals from all sensor channels (by the choice of an operator) are displayed on a monitor screen in on-line regime (Fig. 3). Data from all 
channels are recorded in a file $\left({ }^{*} \cdot \log\right.$, ASCII codes) and stored on a hard disk.

Operating parameters:

- pulse duration of LED glow $\tau=160 \mathrm{~ms}$;

- pulse repetition rate $f=348 \mathrm{~Hz}($ period $T=$ $=2.87 \mathrm{~ms}$ );

- LED current is adjustable from 0 to $150 \mathrm{~mA}$ (at a voltage of 0 to $5 \mathrm{~V}$ );

- range of digital signal values displayed on the monitor and recorded in a file is -32768 to 32768 units.

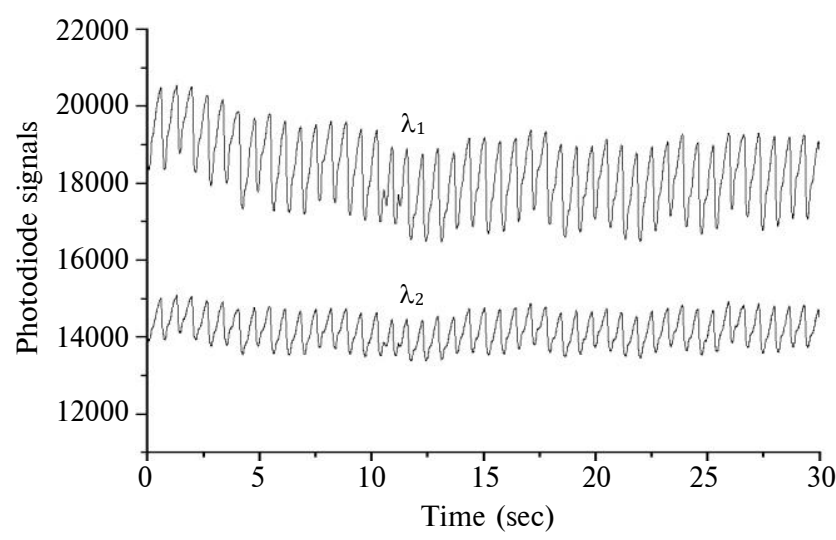

Figure 3: Photodiode signals after the amplifier and ADC processing

A group of 33 persons (thereafter experimentees) has participated in the experiment. Experimental study of changes oxygen saturation of arterial blood under laser irradiation imply the registration of small saturation variations on the background of natural oscillations associated with both the respiratory rhythm and slow waves of first and second order.

During experiments values, oxygen saturation of arterial blood was measured at the state of rest (no radiation is exposed) and its changes under the influence of laser radiation were also measured. To reduce the experimentee's involuntary movements which are likely to induce some noise in photoplethysmogram signals the sensor was built as a clothespin with adjustable pressing force on a finger (see Fig. 2). Then the signal stability is improved significantly.

Measurements were carried out using the pulse-oximetry sensor covering the first phalanx of a finger, and laser radiation was directed to the side of the second phalanx (Fig. 4) [6]. The He-Ne laser with a wavelength of $632 \mathrm{~nm}$ was used as a source of electromagnetic radiation.

Observational values of the geomagnetic field (GMF) with a high-time resolution (1-sec) are obtained from the midlatitude Hurbanovo Geomag- netic Observatory (Slovak Republic), which is a member of the INTERMAGNET family. Such a frequency of measurements makes it possible to analyze the GMF ultra-low frequency components $\leq 1 \mathrm{~Hz}$ from the dataset. The specialized software for calculation of ultra-low frequency $(f \leq 1 \mathrm{~Hz})$ values of GMF was developed. The software uses a basic version of $\mathrm{R}$-interpreter and additionally installed package "Seewave-1.7.6" including "FFT" and "Signal" packages for filtration and fast Fourier transform of digital signals. On $3 \mathrm{MB}$ of source data, there fall $200 \mathrm{kB}$ of final data after processing. The GMF X-component variations data are chosen for computation. Deviations/oscillation ranges regarding the average value were calculated at all frequencies, and low pass filter was applied from the Seewave package (F-filter) for frequencies of $0.1,0.5,0.01,0.05,0.001$, and $0.0001 \mathrm{~Hz}$.

The data on magnetic storms for 2015 were derived from the file of Kyoto Geomagnetic Center (World Data Center for Geomagnetism; http://wdc.kugi.kyoto-u.ac.jp/wdc/expdata.html) which indicated the dates and the amplitudes of magnetic storms on the Earth.

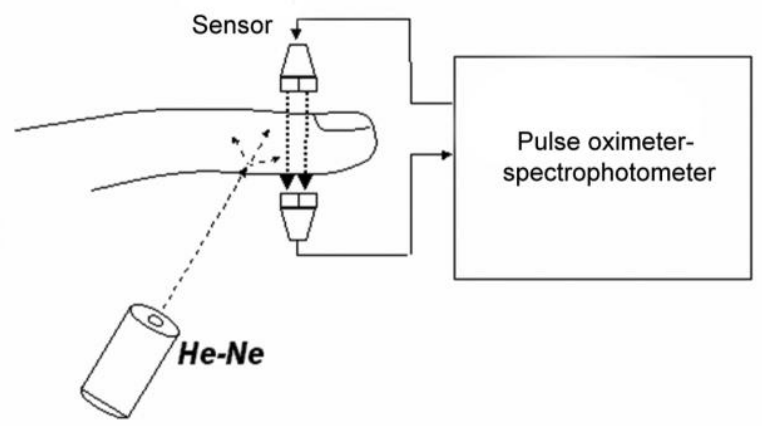

Figure 4: Scheme of the experiment

\section{Results}

The following variables were analyzed: the average arterial oxygen saturation at the patient's rest, peak-to-peak value of saturation, changes in the average oxygen saturation under laser radiation. A group of 33 persons was daily monitored from March 30, 2015, to May 25, 2015. The value of arterial blood saturation with oxygen was determined by the method described in [7]. The data obtained in the days of the unperturbed geomagnetic field acted as a kind of control group. Signal quality was assessed by correlation coefficient $R$ between signals of red and infrared channels.

The results obtained are summarized in the Table. 
The typical plots of parameters studied are shown in Figs. 5 and 6. As seen, the signal quality is high indeed since the correlation coefficient $R>0.99$ (upper plots).

In the presence of Earth's magnetic field disturbances the average value of arterial oxygen saturation at the state of rest in 29 persons out of 33 was $93.9 \pm 0.9 \%$, peak-to-peak value of oxygen was $1.25 \pm 0.24 \%$, and the change in the average arterial oxygen saturation under laser radiation made up $2.34 \pm 0.41 \%$. In all cases, the correlation coefficient exceeded 0.99. Typical graphs are shown in Figs. 7 and 8. In 4 persons under study the peak-to-peak value of saturation at rest did not differ from the case of the undisturbed GMF.

\section{Discussion}

The group of the surveyed can be divided into two parts: the majority show a response to changes

Table: Dynamics of the ultralow-frequency oxygen saturation parameters in arterial blood analyzed during both the undisturbed and disturbed GMF $(p \leq 0,05)$

\begin{tabular}{lccc}
\hline \multicolumn{1}{c}{ Conditions } & \multicolumn{2}{c}{ Quiet state of an experimentee } & $\begin{array}{c}\text { Experimentee } \\
\text { under laser radiation }\end{array}$ \\
\cline { 2 - 4 } & $\begin{array}{c}\text { Mean } \\
\mathrm{SaO}_{2}, \%\end{array}$ & $\begin{array}{c}\text { Oscillation range of the } \\
\text { oxysaturation value } \Delta \mathrm{SaO}_{2}, \%\end{array}$ & $\begin{array}{c}\Delta \mathrm{SaO}_{2}, \%, \text { due to } \\
\text { laser radiation }\end{array}$ \\
\hline Undisturbed GMF & $95.3 \pm 0.6$ & $0.85 \pm 0.08$ & $4.23 \pm 0.12$ \\
Disturbed GMF & $93.9 \pm 0.9$ & $1.25 \pm 0.24$ & $2.34 \pm 0.45$ \\
\hline
\end{tabular}

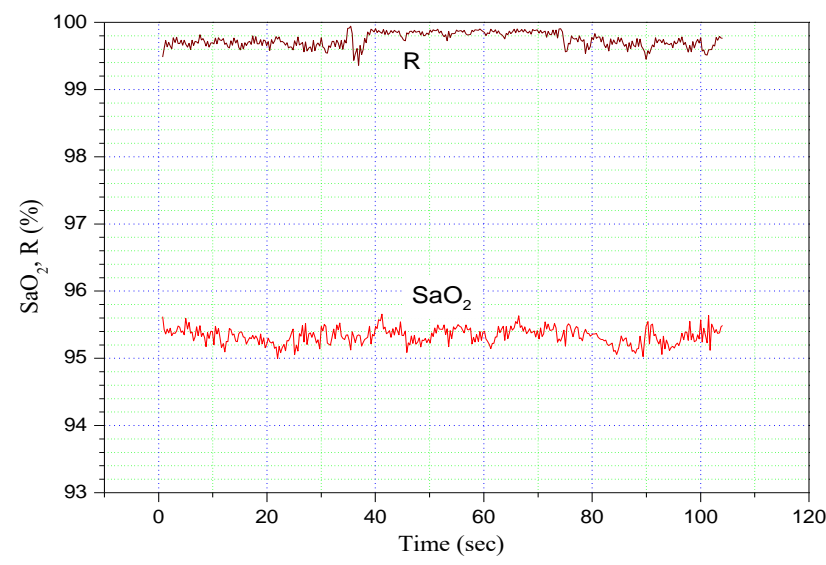

Figure 5: The oscillation range of the oxygen saturation value $\left(\mathrm{SaO}_{2}\right)$ in the arterial blood of an experimentee at rest in case of the undisturbed geomagnetic field

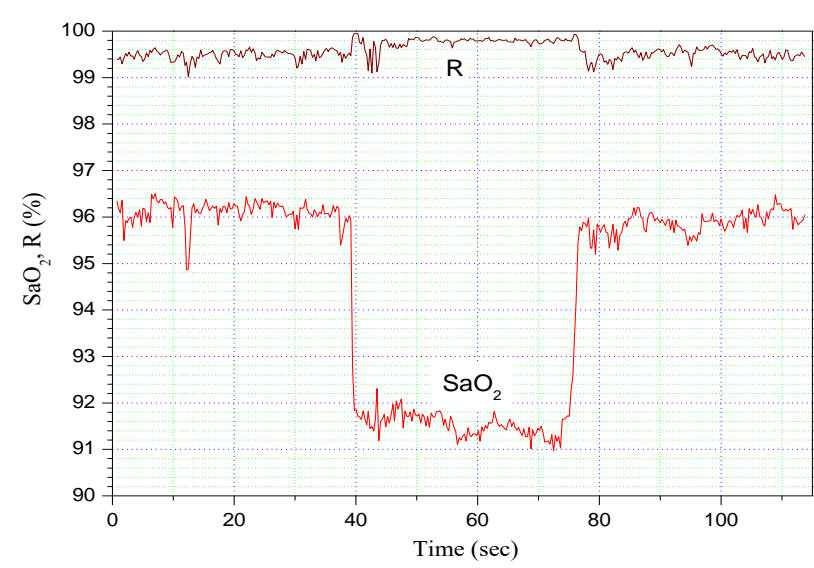

Figure 6: The oscillation range of the oxygen saturation value $\left(\mathrm{SaO}_{2}\right)$ in the arterial blood of an experimentee exposed to laser radiation in case of the undisturbed geomagnetic field

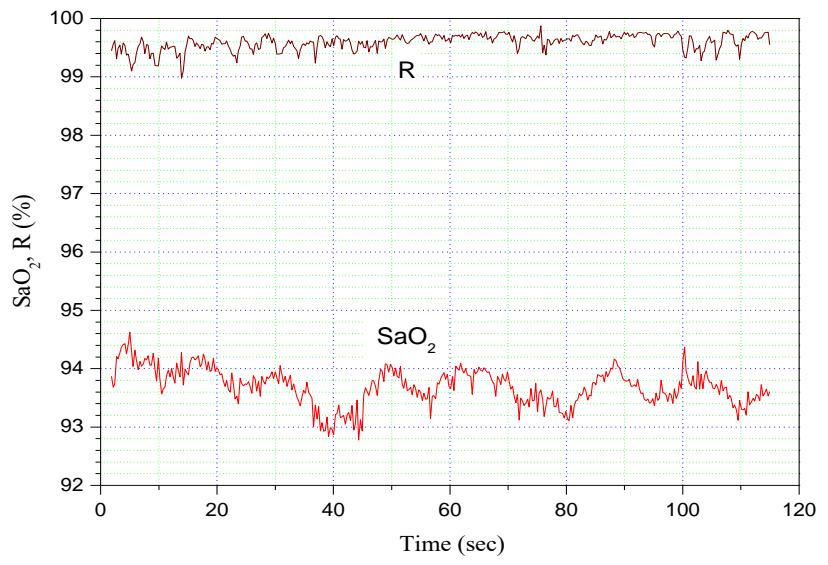

Figure 7: The oscillation range of the oxygen saturation value $\left(\mathrm{SaO}_{2}\right)$ in the arterial blood of an experimentee at rest in case of the disturbed geomagnetic field

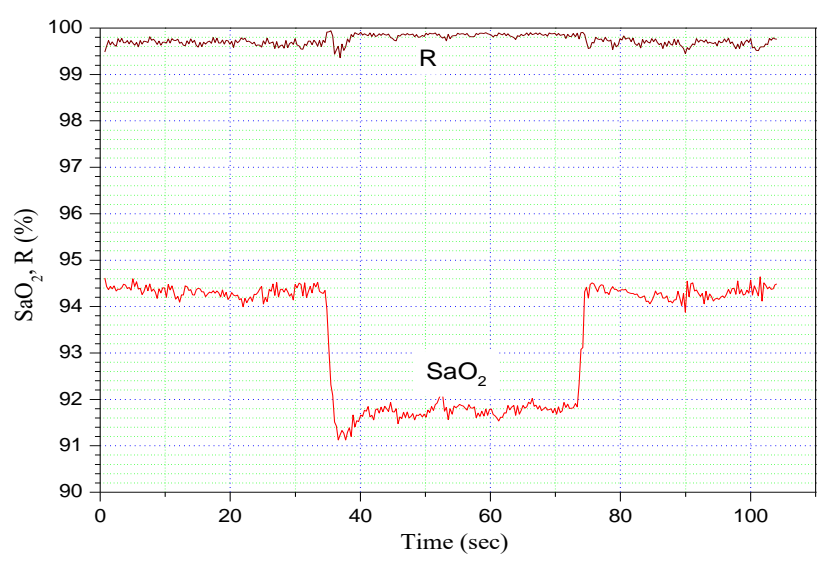

Figure 8: The oscillation range of the oxygen saturation value $\left(\mathrm{SaO}_{2}\right)$ in the arterial blood of an experimentee exposed to laser radiation in case of the disturbed geomagnetic field 
in the magnetic field, a smaller part is resistant to the effects of changes in the magnetic field. This observation confirms our previous studies [8].

In the first case of the disturbed GMF, the $\mathrm{SaO}_{2}$ value is lower and $\Delta \mathrm{SaO}_{2}$ due to laser radiation is rather moderate. The influence of the disturbed GMF on parameters of the human blood oxygen saturation is quite apparent. However, further investigations are needed. Such theoretical assumptions have been made by V.N. Binhi [9].

People who do not react to disturbances of the geomagnetic field, in general, are not subjected to tick attacks even in areas with their high concentration.

We believe that the magnitude of oxygen saturation of arterial blood, its oscillations, and the degree of its reduction under the action of lowintensity laser radiation can serve as an estimating factor of the magnetic field perturbation force, what is included in the task of a reliable study of the effects of parameters of the Earth's magnetic field on animals and humans [3].

\section{Conclusions}

The results of this study of some blood parameters, namely the oxygen saturation (and oxygenation) value are arterial blood and its dynamics due to exposed laser radiation in case of both the undisturbed and disturbed GMF can be summarized as follows:

- the decrease of the blood oxygenation in case of the disturbed GMF (magnetic storm conditions) is quite apparent although more detailed statistical investigations along with biophysical explanations are needed;

- the presence of some experimentees in the observed group who have a constant sweep of arterial blood oxygen saturation is, in our opinion, an aspect to explain the different frequency of tick attacks on various people although strict medical and epidemiological investigations are needed;

the dynamics of the decrease of oxygen saturation in the arterial blood of human beings exposed to laser radiation, in persons with sensitivity to radiation, may be an indicator of the degree of influence of perturbations of the GMF.

\section{References}

[1] Hanslmeier A. The sun and space weather. Netherlands: Springer; 2007. 127 p.

[2] Gorgo YuP, Razumovskiy AK. On the question of determining the effect of high-frequency parameters of Earth's magnetic field on biological objects. Molodii Vchenii. 2015;6(1):8-11.

[3] Ragul'skaya MV, Gorgo YuP, Didyk LA. Biotropic impact of space weather. In: Chibisov SM, Katinas GS, Ragul'skaya MV, editors. Biorhythms and Cosmos: monitoring cosmobiosphere relations. Moscow; 2010. 312 p.

[4] Gorgo YuP, Pet'ko B, Didyk LA, Prigancová A, Mamilov SA. Slight atmospheric pressure fluctuations as a significant predictor for bioobjects meteotropic reactions. Abstracts of XI International conference on bionic, biocybernetics, and applied biophysics; 2010 Nov 4-6; Kyiv. p. 31.

[5] Asimov MM, Asimov RM, Rubinov AN, Mamilov SA, Plaksiy YuS. High sensitive pulseoximeter-spectrophotometer for laser optical dosimetry in biology and medicine. Proc SPIE. 2006;6251:147-54. DOI: 10.1117/12.677684

[6] Mamilov SO. Photodissociation oxyhemoglobin in arterial blood under the laser in vivo. Bulletin of Taras Shevchenko National University of Kyiv Phys Math. 2008;3:202-4.

[7] Kravchenko VI, Minov OM, Mamilov SO, Plaksij YuS, inventors. Method for determining blood oxygen saturation. Ukraine patent 31291A. 1998.

[8] Didyk L, Gorgo Y, Prigancová A, Túnyi I, Vaczyova M, Mamilov S, et al. The effects of atmospheric pressure fluctuations on human behaviour related to injury occurrences: study on the background of low and moderate levels of geomagnetic activity. ISRN Meteorology. 2012;2012:791524. DOI: 10.5402/2012/791524

[9] Binhi VN. Principles of electromagnetic biophysics. Moscow: Fizmatlit; 2011. 592 p.

Проблематика. Відомо, що напруженість геомагнітного поля різко змінюється під час глобальних магнітних збурень, які визначаються як магнітні бурі. Це пов'язано зі зміною сонячної активності, яка впливає на параметри сонячного вітру і стан магнітосфрери. Цей ланцюжок фрізичних процесів з їх походженням на Сонці має назву космічна погода. Важливим є розуміння впливу космічної погоди на навколишнє середовище і біосферу. Зокрема, низькочастотна динаміка геомагнітного поля, яка пов'язана з умовами космічної погоди, видається цілком імовірним фактором, що впливає на стан людини і біологічних об'єктів під час магнітних бур. 
Мета. У роботі досліджується динаміка величини сатурації артеріальної крові киснем з урахуванням екстремальної космічної погоди при виникненні магнітних бур.

Методика реалізації. Експериментальна установка для вимірювання величини відносної концентрації оксигемоглобіну в артеріальній крові (сатурації артеріальної крові киснем) являє собою спеціалізований пульсоксиметр-спектрофотометр. Виміри проводились за допомогою пульсоксиметричного датчика, що покриває першу фалангу пальця, а лазерне випромінювання спрямовувалось на другу фалангу. Як джерело електромагнітного випромінювання використовувався Не-Ne-лазер із довжиною хвилі 632 нм. Значення геомагнітного поля з високим часовим розділенням (1 с) отримані в Гурбанівській геомагнітній обсерваторії (Словацька Республіка). Наднизькочастотні складові геомагнітного поля (0,1, 0,5, 0,01, 0,05, 0,001 і 0,0001 Гц) одержані за допомогою програмного пакета "Seewave-1.7.6". Дані про магнітні бурі за 2015 рік були отримані з файлу Кіотського геомагнітного центру, в якому вказані дати й амплітуди магнітних бур на Землі.

Результати. Було проаналізовано такі величини: середня величина сатурації артеріальної крові киснем у стані спокою, розмах коливань величини сатурації, зміни середньої величини сатурації під дією лазерного випромінювання. Моніторинг проводився щодня з 30 березня по 25 травня 2015 р. для групи з 33 осіб. За наявності збурень магнітного поля Землі середнє значення величини сатурації артеріальної крові киснем у стані спокою в 29 осіб із 33 становило 93,9 \pm 0,9\%, розмах коливання величини сатурації становив 1,25 $\pm 0,24 \%$, а зміна середньої величини сатурації артеріальної крові киснем під дією лазерного випромінювання була 2,34 \pm 0,41 \%. У 4 досліджуваних розмах значень сатурації артеріальної крові в спокої не відрізнявся від випадку незбуреного геомагнітного поля.

Висновки. Результати дослідження параметрів крові, а саме величини сатурації (i отже, оксигенації) артеріальної крові та ії динаміки, обумовленої впливом лазерного випромінювання у випадку як незбуреного, так і збуреного геомагнітного поля, можна узагальнити таким чином: зниження оксигенації крові в разі порушення геомагнітного поля (умови магнітної бурі) цілком очевидне, хоча необхідні більш детальні статистичні дослідження поряд з біофізичними поясненнями; присутність кількох людей у спостережуваній групі, які мають постійний розмах величини сатурації артеріальної крові киснем, є, на нашу думку, одним із фракторів, що пояснює різну частоту нападу кліщів на різних людей, хоча необхідні суворі медичні та епідеміологічні дослідження; динаміка зменшення величини сатурації артеріальної крові киснем під дією лазерного випромінювання у осіб, які мають чутливість до випромінювання, може буди показником ступеня впливу збурень геомагнітного поля.

Ключові слова: сатурація артеріальної крові киснем; геомагнітне поле; лазер; опромінювання.

\section{С.А. Мамилов, Ю.П. Горго, С.С. Есьман, М. Вациова, А. Приганцова, Б. Петко}

\section{САТУРАЦИЯ АРТЕРИАЛЬНОЙ КРОВИ КИСЛОРОДОМ И ЕЕ ДИНАМИКА В СООТВЕТСТВИИ С ЭЛЕКТРОМАГНИТНЫМ СОСТОЯНИЕМ ОКРУЖАЮЩЕЙ СРЕДЫ}

Проблематика. Известно, что напряженность геомагнитного поля резко изменяется во время глобальных магнитных возмущений, определяемых как магнитные бури. Это связано с изменяющейся солнечной активностью, влияющей на параметры солнечного ветра и состояние магнитосферы. Эта цепочка физических процессов с их происхождением на Солнце называется космической погодой. Важным является понимание влияния космической погоды на окружающую среду и биосферу. В частности, низкочастотная динамика геомагнитного поля, связанная с условиями космической погоды, представляется вполне вероятным фрактором, влияющим на состояние человека и биологических объектов во время магнитных бурь.

Цель. В данной работе исследуется динамика величины сатурации артериальной крови кислородом с учетом экстремальной космической погоды при возникновении магнитных бурь.

Методика реализации. Экспериментальная установка для измерения величины относительной концентрации оксигемоглобина в артериальной крови (сатурации артериальной крови кислородом) представляет собой специализированный пульсоксиметр-спектрофотометр. Измерения проводились с помощью пульсоксиметрического датчика, покрывающего первую фралангу пальца, а лазерное излучение направлялось на вторую фалангу. В качестве источника электромагнитного излучения использовался Не-Ne-лазер с длиной волны 632 нм. Значения геомагнитного поля с высоким временным разрешением (1 с) получены в Гурбановской геомагнитной обсерватории (Словацкая Республика). Сверхнизкочастотные составляющие геомагнитного поля $(0,1,0,5,0,01,0,05,0,001$ и 0,0001 Гц) получены с помощью программного пакета “Seewave-1.7.6”. Данные о магнитных бурях за 2015 год были получены из файла Киотского геомагнитного центра, в котором указаны даты и амплитуды магнитных бурь на Земле.

Результаты. Были проанализированы следующие величины: средняя величина сатурации артериальной крови кислородом в состоянии покоя, размах колебаний величины сатурации, изменения средней величины сатурации под действием лазерного излучения. Мониторинг проводился ежедневно с 30 марта по 25 мая 2015 г. для группы из 33 человек. При наличии возмущений магнитного поля Земли среднее значение величины сатурации артериальной крови кислородом в состоянии покоя у 29 человек из 33 составляло 93,9 $\pm 0,9 \%$, размах колебания величины сатурации составил $1,25 \pm 0,24 \%$, а изменение средней величины сатурации артериальной крови кислородом под действием лазерного излучения составило 2,34 $\pm 0,41 \%$. У 4 исследуемых размах значений сатурации артериальной крови в покое не отличался от случая невозмущенного геомагнитного поля.

Выводы. Результаты исследования параметров крови, а именно величины сатурации (и значит, оксигенации) артериальной крови и ее динамики, обусловленной воздействием лазерного излучения в случае как невозмущенного, так и возмущенного геомагнитного поля, можно обобщить следующим образом: снижение оксигенации крови в случае нарушения геомагнитного поля (условия магнитной бури) вполне очевидно, хотя необходимы более подробные статистические исследования наряду с биофизическими объяснениями; присутствие нескольких людей в наблюдаемой группе, которые имеют постоянный размах величины сатурации артериальной крови кислородом, является, по нашему мнению, одним из фракторов, объясняющих различную частоту нападения клещей на разных людей, хотя необходимы строгие медицинские и эпидемиологические исследования; динамика уменьшения величины сатурации артериальной крови кислородом под действием лазерного излучения у лиц, которые имеют чувствительность к излучению, может быть показателем степени влияния возмущений геомагнитного поля.

Ключевые слова: сатурация артериальной крови кислородом; геомагнитное поле; лазер; облучение. 